\title{
HAKIKAT SAINS DAN INKUIRI
}

\section{A. Hakikat Sains}

\section{Pengertian Hakikat Sains}

Sains dalam bahasa inggris science berasal dari bahasa latin, yaitu "scientia" yang berarti (1) pengetahuan (knowlegde); (2) pengetahuan, pengertian, faham yang benar dan mendalam (Fisher, 1975). Menurut James Conan, sains sebagai deretan konsep serta skema konseptual yang berhubungan satu sama lain, dan yang tumbuh sebagai hasil eksperimentasi dan observasi, serta berguna untuk diamati dan dieksperimentasikan lebih lanjut. Menurut Toharudin, et al.,(2011) ilmu pengetahuan alam sering pula disebut sains, sains memiliki sifat dan karakteristik yang unik yang membedakannya dari ilmu lainnya. Wonoraharjo (2010) menguatkan bahwa ilmu pengetahuan alam (IPA) adalah sekumpulan pengetahuan yang diperoleh melalui metode tertentu. Proses pencariannya telah diuji kebenarannya secara bersama-sama oleh beberapa ahli sains dan pemirsanya.

Sains merupakan tubuh dari pengetahuan (body of knowledge) yang dibentuk melalui proses inkuiri yang terus menerus (Fisher, 1975; Zuhdan dalam Istiyono, 2010). Menurut Mariana \& Praginda (2009) sains adalah ilmu pengetahuan atau kumpulan konsep, prinsip, hukum, dan teori yang dibentuk melalui proses kreatif yang sistematis melalui inkuiri dengan proses observasi (empiris) secara terus-menerus yang melibatkan operasi mental, dengan dilandasi sikap ingintahu, keteguhan hati, ketekunan, dan dapat diuji kembali kebenarannya untuk mengungkapkan rahasia alam semesta.

Samatowa (2010) menjelaskan bahwa ilmu pengetahuan alam (IPA) atau sains dalam arti sempit sebagai disiplin ilmu dari physical science dan life science. Yang termasuk physical science adalah ilmu-ilmu astronomi, kimia, geologi, mineralogi, meteorologi, dan fisika; sedangkan life science meliputi biologi (anatomi, fisiologi, zoologi, citologi, dan seterusnya. Ahli lain menyatakan bahwa hakikat sains atau Nature of Science (NoS) merupakan pengetahuan tentang epistemologi (metode) dari sains, proses terjadinya sains, atau nilai dan keyakinan yang melekat untuk mengembangkan sains (Khalick, et al., 1997). Pendapat tersebut diperkuat oleh Carin and Sund dalam Wenno (2008) bahwa hakikat sains meliputi scientific product, scientific processes, dan 
scientific attitudes. Produk sains yang meliputi fakta, konsep, prinsip diperoleh melalui serangkaian proses penemuan ilmiah dengan metode ilmiah dan didasari oleh sikap ilmiah.

Menurut Toharudin, et al., (2011) hakikat sains terdiri dari sians sebagai proses, sains sebagai produk dan sians sebagai sikap. Berikut penjabaran masing-masing aspek:

a. Sains sebagai Proses

Sains sebagai proses, merupakan aktivitas kognitif. Sains sebagai proses akan selalu merujuk pada suatu aktivitas ilmiah yang dilaksanakan oleh para ahli sains. Setiap aktivitas ilmiah mempunyai ciri-ciri yang rasional, kognitif dan bertujuan. Aktivitas seorang dalam mencari ilmu pasti memerlukan pikiran untuk menalarnya. Dalam melaksanakan ktivitas ilmiah yang merupakan kegiatan terbaik harus dipayungi oleh kegiatan yang bernama penelitian

b. Sains sebagai sikap

Sikap ilmiah pada dasarnya adalah sikap yang diperlihatkan oleh ilmuan saat mereka melakukan berbagai kegiatan ilmiah terkait dengan profesinya sebagai seoarang ilmuwan. Dengan perkataan lain, sikap ilmiah merupakan kecenderungan individu untuk bertindak atau berperilaku dalam memecahkan masalah sistematis melalui langkah-langkah. Karena itu, seorang peneliti harus mampu mengembangkan beberapa sikap ilmiah.

c. Sains sebagai produk

Sains sebagai produk ilmiah, dapat berupa pengetahuan-pengetahuan sains yang didapat dari bahan ajar, makalah-makalah ilmiah, buku teks, artikel ilmiah dan pernyataan para ahli sains berupa teori, postulat, hukum dan lain-lain. Secara umum, ada beberapa produk sians seperti faka, konsep, lambang, konsepsi atau penjelasan dan teori.

Berdasarkan definisi dari para ahli dapat disimpulkan bahwa sains adalah suatu cara untuk memperoleh pengetahuan baru yang berupa produk ilmiah dan sikap ilmiah melalui suatu kegiatan yang disebut proses ilmiah. Siapapun yang akan mempelajari sains haruslah melakukan suatu kegiatan yang disebut sebagai proses ilmiah. Seseorang dapat menemukan pengetahuan baru dan menanamkan sikap yang ada dalam dirinya melalui. 
Sains ditempuh melalui berbagai proses penyelidikan secara berkelanjutan, yang berkontribusi dengan berbagai cara untuk membentuk sistem yang unik. Seorang sains juga dituntut untuk memiliki sikap ilmiah seperti rasa ingin tahu, disiplin dan lain-lain. Salah satu proses yang ditempuh para ilmuwan dalam mengembangkan sains adalah metode ilmiah (scientific method). Menurut Roshayanti, et al. (2014) ada beberapa variasi dalam metode ilmiah, tetapi pada umumnya langkah metode ilmiah terdiri atas: merumuskan masalah; membuat hipotesis; Mengujikan hipotesis (eksperimen); menghimpun dan analisis data (hasil); dan menarik kesimpulan.

\section{Aspek Hakikat Sains}

NoS mempunyai tujuh aspek sebagaimana dijelaskan oleh (Khalick, et al., 1997) bahwa karakteristik sains sesuai dengan tingkat ilmu pengetahuan yaitu 1) Tentatif (dapat berubah sewaktu-waktu), 2) Empiris (berdasarkan pengamatan atau observasi), 3) Metode ilmiah, 4) Imajinasi dan kreativitas manusia, 5) Sosial dan budaya serta 2 aspek tambahan yaitu 1) Subjektif, 2) Hubungan teori dan hukum ilmiah.

Aspek-aspek nature of science menurut Khalick, et al., (1997) adalah sebagaimana dijelaskan pada Tabel 1. Berikut.

Tabel 1. Aspek-aspek Nature of Science

\begin{tabular}{lll}
\hline No & Spek NoS & Indikator soal \\
\hline 1 & Tentatif & $\begin{array}{l}\text { Memahami sifat tentatif ilmiah sebagai bagian dari sains } \\
\text { Memahami peran empiris dalam menghasilkan pengetahuan } \\
\text { ilmiah }\end{array}$ \\
Empiris & $\begin{array}{l}\text { Metode Ilmiah } \\
\text { Imajinasi dan } \\
\text { kreativitas manusia }\end{array}$ & $\begin{array}{l}\text { Memahami peran model ilmiah dalam ilmu pengetahuan } \\
\text { ilmu pengetahaun } \\
\text { Memahami keterkaitan sosial dan budaya dalam ilmu }\end{array}$ \\
5 & $\begin{array}{l}\text { Sosial dan budaya } \\
\text { pengetahaun }\end{array}$ \\
6 & Subjektif & $\begin{array}{l}\text { Menilai keyakinan siswa tentang faktor yang berhubungan } \\
\text { dengan pendapat pribadi dan anggapan yang berdasarkan } \\
\text { teoritis }\end{array}$ \\
7 & Hubungan teori dan & $\begin{array}{l}\text { Mendapatkan kesalahpahaman umum tentang hubungan } \\
\text { antara produk ilmu pengetahuan }\end{array}$ \\
\hline
\end{tabular}




\section{B. Hakikat Pendidikan Sains}

\section{Pengertian}

Hakikat Pendidikan Sains menurut Kirkham (Wellington, 1989) merupakan akumulasi dari content, process dan context. Content menyangkut hal-hal yang berkaitan dengan fakta, definisi, konsep, prinsip, teori, model dan terminologi. Process berkaitan dengan keterampilan untuk memperoleh atau menemukan konsep dan prinsip. Context meliputi tiga elemen yaitu individu, masyarakat dan keseluruhan pengalaman sekolah (kurikulum). Sains atau IPA bagi banyak mahasiswa calon guru adalah body of knowledge yang berisi kumpulan hasil observasi dan penelitian yang menjelaskan apa, mengapa, dan bagaimana suatu fenomena terjadi (Aguirre \& Haggerty, 1995; Gustafon \& Rowell, 1995).

Pembelajaran sains (IPA) tidak terlepas dari hakikat sains itu sendiri, bahwa sains dipandang sebagai a body of knowledge (sains sebagai sekumpulan pengetahuan), a way of thinking (sains sebagai cara berpikir), dan a way of investigating (sains sebagai cara penyelidikan). Hal ini menunjukkan bahwa pembelajaran sains melibatkan penggunaan sejumlah panca indera, hands-on dan minds-on.

\section{Karakteristik}

Menurut Djojosoediro karakteristik IPA adalah: mempunyai nilai ilmiah; merupakan suatu kumpulan pengetahuan yang tersusun secara sistematis, dan dalam penggunaannya secara umum terbatas pada gejala-gejala alam; merupakan pengetahuan teoritis yang diperoleh atau disusun dengan cara yang khas atau khusus; merupakan suatu rangkaian konsep yang saling berkaitan dengan baganbagan konsep yang telah berkembang sebagai suatu hasil eksperimen dan observasi, yang bermanfaat untuk eksperimentasi dan observasi lebih lanjut; IPA meliputi empat unsur, yaitu produk, proses, aplikasi dan sikap.

Sains dan teknologi memiliki hubungan yang sangat erat dan saling melengkapi. Penemuan dalam sains memungkinkan pengembangan teknologi berupa instrumen baru yang dapat digunakan untuk melakukan observasi dan percobaan sains. Perkembangan 
sains sangat ditunjang oleh teknologi. Perubahan sains harus merefleksikan atau mengarahkan pada masalah yang dihadapi manusia dalam kehidupan sehari-hari.

Menurut De Boer (1991), orang yang sadar sains adalah orang yang dapat menggunakan konsep-konsep sains, ketrampilan proses sains dan nilai-nilai dalam membuat keputusan sehari-hari dalam interaksinya dengan lingkungannya, juga memahami hubungan antara sains, teknologi dan masyarakat. Melalui pendidikan sains, peserta didik diharapkan dapat memahami sains dan mampu menerapkan dalam kehidupan sehari-hari untuk memecahkan berbagai masalah. Oleh karena itu, kurikulum hendaknya mampu mendorong peserta didik agar dapat berpikir secara benar sebagaimana dalam kaidah hakikat sains.

\section{Tujuan}

Menurut De Boer (1991), kurikulum pendidikan sains harus sesuai dengan tujuan pendidikan sains. Adapun tujuan pendidikan sains yang diharapkan adalah 1) meningkatkan kesejahteraan masyarakat melalui pendidikan; 2) mengembangkan hubungan sains dan keindahan alam; 3) menarik minat peserta didik untuk melakukan studi lanjut pada bidang sains; 4) mengembangkan kemampuan peserta didik untuk mengobservasi, membuat pengukuran yang teliti terhadap suatu fenomena, mengklasifikasikan pengamatan dan membuat penalaran secara jelas terhadap hasil pengamatan; 5) pemahaman yang jelas tentang prinsip-prinsip masing-masing cabang sains (fisika, kimia dan biologi).

Lawson (1995) memberikan pendapat bahwa pembelajaran sains bertujuan untuk membantu siswa mengembangkan keterampilan berpikir kritis dan kreatif, kebebasan dalam berfikir, membangun penguasaan konsep esensial, serta bentuk-bentuk dasar berfikir saintifik, membangun kepercayaan diri dalam mengajukan masalah atau pertanyaan serta menyelesaikannya atau mencari pemecahannya.

Tujuan pendidikan sains pada hakikatnya adalah membelajarkan peserta didik untuk memahami hakikat sains (proses dan produk serta aplikasinya) dengan mengembangkan sikap ingin tahu, keteguhan hati, ketekunan dan sadar akan nilai-nilai yang ada di dalam masyarakat, serta mengembangkannya ke arah sikap positif. Secara 
lebih rinci, tujuan pendidikan pendidikan sains mencakup lima dimensi, yaitu pengetahuan dan pemahaman (scientific information), penggalian dan penemuan (exploring and discovering; scientific process), imajinasi dan kreativitas, sikap dan nilai, serta dimensi penerapan sains.

\section{Pentingnya Hakikat Pendidikan Sains}

Hakikat pendidikan sains dipandang berfaedah bagi suatu bangsa. Kesejahteraan materil suatu bangsa banyak sekali tergantung kepada kemampuan bangsa itu dalam bidang sains, sebab sains merupakan dasar teknologi. Sedangkan teknologi disebut-sebut sebagai tulang punggung pembangunan. Suatu teknologi tidak akan berkembang pesat jika tidak didasari pengetahuan dasar yang memadai. Sedangkan pengetahuan dasar untuk teknologi adalah IPA (Sumatowa, 2010).

Driver, et al., (1996) memaparkan lima argumen singkat mengapa pemahaman NoS penting. Argumen tersebut yaitu: 1) utilitarian, memahami NoS diperlukan untuk memahami ilmu pengetahuan dan mengelola benda-benda teknologi dan proses dalam kehidupan sehari-hari, 2) democratic, memahami NoS diperlukan untuk informasi pengambilan keputusan pada isu-isu socioscientific, 3) cultural, memahami NoS perlu untuk menghargai nilai ilmu sebagai bagian dari budaya kontemporer, 4) moral, memahami NoS membantu mengembangkan pemahaman tentang norma-norma komunitas ilmiah yang mewujudkan komitmen moral tentang nilai umum kepada masyarakat, 5) science learning, memahami NoS memfasilitasi pembelajaran materi mata pelajaran sains

\section{Implikasi dan Implementasi Pembelajaran Sains}

Fakta di lapangan tentang pemahaman hakikat sains bahwa banyak guru dan siswa yang tidak memahami hakikat sains (Pomeroy, 1993). Adanya miskonsepsi siswa tentang hakikat sains akibat miskonsepsi guru. Pemahaman NoS yang baik dari guru akan mempengaruhi pemahaman siswanya (Khalick, et al., :1997). Hasil penelitian Roshayanti, et al. (2016) tentang pemahaman NoS siswa SMA se-Kota Tegal diperoleh hasil bahwa dari 250 siswa $54 \%$ diantaranya berada dalam kondisi kurang menguasai 
NoS, 34\% kurang sekali, $11 \%$ cukup, $1 \%$ baik, dan $0 \%$ baik sekali. Kondisi ini menunjukkan bahwa pemahaman NoS siswa SMA di Kota Tgal relatif masih rendah.

Data tersebut didukung oleh hasil wawancara terhadap guru-guru sains yang mengajar di Sekolah tersebut. Sebagian besar guru merasa kurang paham tentang Natur of Science (NoS). Hal tersebut terlihat dari hasil wawancara yang kami himpun sebagai berikut.

- \#Jujur, Saya baru mendengar istilah NoS (WG.SMAS E.18/05/2016)

- \#Kalo istilah itu saya ngga tahu, tapi saya tahu back to nature (WG.SMAS A.18/05/2016)

- \#Saya belum tahu apa itu NoS (WG.SMAN C.16/05/2016)

- \#Itu hakikat IPA ya, tapi untuk detailnya saya kurang begitu tahu (WG.SMAN A.11/05/2016)

Berdasarkan beberapa fakta dan temuan tersebut, guru seharusnya menyadari dan yakin bahwa pengajaran hakikat sains tersebut adalah penting dan dapat dipahami (kontekstual dan bermakna). Oleh karena, yang menyebabkan rendahnya pemahamn hakikat sains pada siswa biasanya disebabkan oleh beberapa faktor berikut: 1) Kurangnya Pemahaman NoS bagi guru; 2) Keterbatasan waktu; 3) Kurikulum; 4) Fasilitas; 5) Niat guru. Adapun implementasi pembelajaran yang menggunakan prinsip hekikat sains diilustrasikan pada lampiran 2.

\section{Indikator Ketercapaian Pembelajaran Sains}

Indikator ketercapaian dalam pembelajaran sains dijelaskan pada dua kondisi, yaitu bagi calon guru dan bagi guru profesional. Tolok ukur ketercapaian pembelajaran sains tersebut memiliki standar minimal masing-masing, yaitu dijelaskan pada Tabel 2 berikut.

Tabel 2. Indikator Ketercapaian Pembelajaran Sains

\begin{tabular}{|l|l|l|}
\hline No & \multicolumn{1}{|c|}{ Calon Guru } & \multicolumn{1}{c|}{ Guru Profesional } \\
\hline 1 & $\begin{array}{l}\text { Merencanakan kegiatan untuk } \\
\text { menyampaikan hakikat ilmu dasar dan } \\
\text { terapan }\end{array}$ & $\begin{array}{l}\text { Secara konsisten mengintegrasikan } \\
\text { kegiatan untuk menyampaikan hakikat } \\
\text { ilmu dasar dan terapan }\end{array}$ \\
\hline 2 & $\begin{array}{l}\text { Membedakan aturan pengetahuan sains } \\
\text { dengan lainnya }\end{array}$ & $\begin{array}{l}\text { Merancang pembelajaran efektif yang } \\
\text { dapat membedakan sains dan non sains }\end{array}$ \\
\hline
\end{tabular}




\begin{tabular}{|l|l|l|}
\hline 3 & $\begin{array}{l}\text { Menjelaskan dan memberikan contoh } \\
\text { konvensi penelitian, menjelaskan } \\
\text { hukum dan teori }\end{array}$ & $\begin{array}{l}\text { Merancang pembelajaran yang } \\
\text { memperlihatkan } \\
\text { pertanyaan, rancangan penelitian, } \\
\text { interpretasi data dipandang oleh } \\
\text { konvensi sains }\end{array}$ \\
\hline 4 & $\begin{array}{l}\text { Menyediakan contoh perubahan dalam } \\
\text { pengetahuan sains sepanjang waktu } \\
\text { mengacu pd sejarah perkembangan } \\
\text { konsep }\end{array}$ & $\begin{array}{l}\text { Secara sistematis melibatkan siswa } \\
\text { dalam inquiry yang menyingung } \\
\text { hakikat sains meliputi perubahan } \\
\text { sejarah dan filosofi yang membentuk } \\
\text { pengetahuan }\end{array}$ \\
\hline
\end{tabular}

\section{Rekomendasi NSTA}

Rekomendasi NSTA terkait hakikat sains adalah sebagai berikut:

a. Hakekat sains harus dipahami semua orang

b. Siswa harus memiliki pemahaman mendasar tentang konvensi dan hakekat sains. Siswa harus terlibat aktif dalam penyelidikan dan analisa dari konvensi sains.

c. Semua prospek guru harus memiliki kesempatan untuk : Mempelajari literatur, Menganalisa, mendiskusikan topik di media seminar perkuliahan yang berhubungan dengan sains

d. Memasukan hakekat sains sebagai tematik dari kurikulumnya.

\section{Inkuiri}

\section{Definisi}

Inkuiri didefinisikan oleh Piaget (Sund dan Trowbridge, 1973) sebagai pembelajaran yang mempersiapkan situasi bagi anak untuk melakukan eksperimen sendiri; dalam arti luas ingin melihat apa yang terjadi, ingin melakukan sesuatu, ingin menggunakan simbol-simbol dan mencari jawaban atas pertanyaan sendiri, menghubungkan penemuan yang satu dengan penemuan yang lain, membandingkan apa yang ditemukan dengan yang ditemukan orang lain. Kuslan Stone (Dahar,1991) mendefinisikan model inkuiri sebagai pengajaran di mana guru dan anak mempelajari peristiwa-peristiwa dan gejala-gejala ilmiah dengan pendekatan dan jiwa para ilmuwan. Bruce \& Bruce (1992) menjelaskan inkuiri merupakan suatu cara mengajar murid-murid 
bagaimana belajar dengan menggunakan keterampilan, proses, sikap, dan pengetahuan berpikir rasional.

Inkuiri berawal dari research training model yang dikembangkan oleh Richcard Schuman (1926) untuk mengajarkan siswa tentang proses dalam meneliti dan menjelaskan fenomena asing pada konsepsi metode ilmiah (Joyce, at al., 2000). Cleaf (1991) menyatakan bahwa inkuiri adalah salah satu pendekatan yang digunakan dalam kelas yang berorientasi proses. Trowbridge (1990) menjelaskan model inkuiri sebagai proses mendefinisikan dan menyelidiki masalah-masalah, merumuskan hipotesis, merancang eksperimen, menemukan data, dan menggambarkan kesimpulan masalahmasalah tersebut.

The National Science Education Standards (NRC, 1996) mendefinisikan inkuiri adalah sebuah kegiatan yang melibatkan pengamatan; mengajukan pertanyaan; memeriksa buku dan informasi dari sumber lain untuk melihat apa yang telah diketahui; perencanaan investigasi; meninjau apa yang sudah dikenal dari bukti percobaan; menggunakan alat untuk mengumpulkan, menganalisis, dan menafsirkan data; mengusulkan jawaban, memberi penjelasan, memprediksi; dan mengkomunikasikan hasil.

Berdasarkan definisi-definisi di atas, dapat disimpulkan bahwa inkuiri merupakan suatu proses yang ditempuh siswa untuk memecahkan masalah, merencanakan eksperimen, melakukan eksperimen, mengumpulkan dan menganalisis data, dan menarik kesimpulan. Dengan demikian, siswa akan terbiasa bersikap seperti para ilmuwan Sains, yaitu teliti, tekun/ulet, objektif/jujur, kreatif, dan menghormati pendapat orang lain.

\section{Karakteristik}

Menurut Beyer (1971) inquiry terdiri atas beberapa komponen, yaitu: proses (process), pengetahuan (knowledge), sikap dan nilai (attitudes and valuess). Kemampuan dasar inkuiri sebagai hasil belajar sains menurut Trowbridge (1973) yaitu: (1) kemampuan mengajukan pertanyaan tentang fenomena alam (asking insightful questions about natural phenomena); (2) kemampuan merumuskan masalah (formulating problems); (3) kemampuan merumuskan hipotesis (formulating hypothesis); (4) 
kemampuan merencanakan penelitian dan metode pengumpulan data (designing investigative approaches including experiment); (5) kemampuan menyimpulkan hasil penelitian (councluding out experiments); (6) kemampuan mengkaitkan hasil penelitian dengan pengetahuan (synthesizing knowledge).

Inquiry mengembangkan dan menggunakan berpikir tingkat tinggi dalam pemecahan masalah, mengembangkan berpikir kritis yang tertanam dalam berbagai proses berbagai ilmu (NSTA \& AEST, 1998). Sementara menurut The National Academy of Sciences (2000) karakteristik inkuiri dalam kelas sains adalah menunjukkan keingintahuan, mendefinisikan pertanyaan dari pengetahuan terbaru; mengajukan hipotesis; merencanakan dan melakukan investigasi sederhana; mengumpulkan bukti dari pengamatan; menjelaskan berdasarkan bukti; mempertimbangkan penjelasan lainnya; mengkomunikasikan penjelasan; dan menguji penjelasan.

\section{Kegunaan Inkuiri}

Dalam pembelajaran inkuiri dapat diartikan beragam, tergantung pada penggunaannya. Inkuiri dapat diartikan sebagai pendekatan atau strategi, model, dan metode pembelajaran. Pemilihan tersebut disesuaikan dengan tujuan pembelajaran yang akan dilaksanakan. Perbedaan dari ketiganya kegunaan tersebut dapat dijelaskan sebagai berikut.

\section{a. Inkuiri Sebagai Pendekatan atau Strategi}

Pendekatan pembelajaran inkuiri adalah rangkaian kegiatan pembelajaran yang menekankan pada proses berfikir secara kritis dan analitis untuk mencari dan menemukan sendiri jawaban dari suatu masalah yang dipertanyakan. (Joyce, et al., 2000). Proses berfikir itu sendiri biasanya dilakukan melalui tanya-jawab antara guru dan siswa. Pendekatan pembelajaran inquiry sering juga dinamakan pendekatan heuristic, yang berasal dari bahasa Yunani (heuriskein) yang berarti saya menemukan (Sanjaya, 2007).

Pendekatan pembelajaran inkuiri berangkat dari asumsi bahwa sejak manusia lahir kedunia, manusia memiliki dorongan untuk menemukan sendiri pengetahuannya. Rasa ingin tahu tentang keadaan alam di sekelilingnya merupakan kodrat manusia 
sejak ia lahir ke dunia. Sejak kecil manusia memiliki keinginan untuk mengenal segala sesuatu melalui indra pengecapan, pendengaran, penglihatan, dan indra-indra lainnya hingga dewasa keingin tahuan manusia secara terus menerus berkembang dengan menggunakan otak dan pikirannya. Pengetahuan yang dimiliki manusia akan bermakna (meaningfull) manakala didasari oleh keingin tahuan itu. Dalam rangka itulah pendekatan inkuiri dikembangkan.

Sanjaya (2007) menjelaskan ciri utama dari pendekatan pembelajaran inkuiri yaitu: 1) menekankan pada aktivitas siswa secara maksimal untuk mencari dan menemukan, siswa sebagai subjek belajar; 2) aktivitas siswa diarahkan untuk mencari dan menemukan jawaban sendiri dari suatu yang dipertanyakan sehingga diharapkan dapat menumbuhkan rasa percaya diri, guru sebagai fasilitator dan mediator belajar siswa; 3) tujuan startegi ini untuk mengembangkan kemampuan berfikir secara sistematis, logis dan kritis, atau mengembangkan kemampuan intelektual sebagai bagian dari proses mental. Sementara menurut Khan dan Iqbal (2010) Pembelajaran berbasis inkuiri mengharuskan siswa aktif mengumpulkan ideide untuk menciptakan pengetahuan dengan sendirinya.

Sanjaya (2007) menambahkan bahwa inkuiri dapat berjalan secara efektif sebagai pendekatan pembelajaran, jika guru memperhatikan beberapa hal berikut.

1) Guru mengharapkan siswa dapat menemukan sendiri jawaban dari suatu permasalaahn yang ingin dipecahkan. Dengan demikian penguasaan materi pelajaran bukan sebgai tujuan utama pembelajaran, akan tetapi lebih dipentingkan adalah proses belajar.

2) Bahan pelajaran yang akan diajarkan tidak berbentuk fakta atau konsep yang sudah jadi, sehingga perlu pembuktian untuk sebuah kesimpulan

3) Proses pembelajaran berangkat dari rasa ingin tahu siswa terhadap sesuatu.

4) Guru akan mengajar pada sekelompok siswa yang rata-rata memiliki kemauan dan kemampuan berfikir. Pendekatan inkuiri akan kurang berhasil diterapkan kepada siswa yang kurang memiliki kemampuan untuk berfikir.

5) Jumlah siswa yang belajaar tak terlalu banyak sehingga bisa dikendalikan oleh guru. 
6) Guru memiliki waktu yang cukup untuk menggunakan pendekatan ini.

Implementasi inkuiri sebagai pendekatan, menurut NRC adalah sebagai berikut:

1) Tahap Undangan (invitation) untuk berinkuiri:

Dalam hal ini siswa mengajukan pertanyaan yang diamati untuk diteliti, pertanyaan di catat dalam buku atau jurnal, pertanyaan didiskusikan di dalam kelas untuk dikomentari oleh teman-temannya, siswa merangkum secara tertulis dan merevisi pertanyaan penelitian berdasarkan tanggapan teman-temannya, akhirnya siswa mengajukan dan mempertahankan pertanyaan penelitiannya di depan kelas.

2) Tahap perencanaan percobaan

Siswa membentuk kelompok dengan anggota yang setuju dengan pertanyaan tersebut, pertanyaan disesuaikan dengan kendala waktu dan sumber daya yang tersedia. Setiap siswa membuat jurnal dalam proses ini. Ketika siswa sudah siap maka rencana kerja dipresentasikan di depan kelas, salinan rencana kerja dibagikan diikuti diskusi dan seminar, kemudian berdasarkan pola tanggapan teman-teman, kritik tertulis, rekomendasi rencana kerja dimodifikasi dan direvisi kembali.

3) Tahap pelaksanaan Percobaan

Setelah rencana matang pelaksanaan penelitian pun dilaksanakan melalui proses merakit dan menguji alat-alat, mendisain dan menguji bentuk-bentuk pengumpulan data, mengembangkan dan menguji jadwal pengumpulan data, kelompok melakkukan pengumpulan, penyusunan, dan interpretasi data.

4) Tahap mengkomunikasikan

Dalam tahap ini kelompok mempersiapkan laporan tertulis untuk menjelaskan penelitian. Data yang dikumpulkan dianalisis dan dimintakan tanggapan temantemannya, jika perlu kelompok mengubah cara kerja dan melanjutkan proses pengumpulan data. Ketika kelompok telah yakin bahwa pengumpulan data telah dilaksanakan dan data yang dikumpulkan konsisten, mereka menganalisis data dan menggambarkan kesimpulan. Sesudah seminar kelompok menyiapkan draft 
laporan. Draft dibagikan kepada teman-temannya untuk mendapatkan tanggapan dan kritikan.

\section{b. Inkuiri sebagai Model}

Model pembelajaran merupakan suatu rencana mengajar yang memperlihatkan pola (syntax) pembelajaran tertentu, dalam pola tersebut dapat terlihat kegiatan gurusiswa (Kartimi dalam Suwara, 2007), termasuk inkuiri. Dari berbagai model yang dikaji dalam model of teaching (Joyce, et al: 2000), model inquiry merupakan salah satu model yang diunggulkan untuk pembelajaran sains di sekolah (Rustaman). Model pembelajaran inkuiri merupakan salah satu model pembelajaran yang dikembangkan berdasarkan cara berpikir yang bersifat penemuan, yaitu menarik kesimpulan berdasarkan data-data yang teramati. Atas dasar ini model pembelajaran inkuiri menekankan pada pengalaman lapangan seperti mengamati gejala atau mencoba suatu proses kemudian mengambil kesimpulan.

Tujuan dari model pembelajaran inkuiri adalah membantu siswa mengembangkan ketrampilan intelektual dan ketrampilan-ketrampilan lainya, seperti mengajukan pertanyaan (Joyce, et al., 2000).

Joyce, et al. (2000) mengelompokkan ada dua jenis model inkuiri, yaitu:

\section{1) Inquiry Training (latihan berinkuiri)}

Dikemukakan oleh Suchaman (Joyce, et al., 2000) pada model ini siswa dilatih untuk berinkuiri. Adapun sintaks pada model ini dijelaskan pada Tabel 3 berikut.

\section{Tabel 3. Sintaks Model Inquiry Training}

\begin{tabular}{|l|l|l|}
\hline No & \multicolumn{1}{|c|}{ Sintaks } & \multicolumn{1}{|c|}{ Deskripsi } \\
\hline 1 & $\begin{array}{l}\text { Fase Pertentangan } \\
\text { terhadap Masalah } \\
\text { (confrontation with } \\
\text { the problem) }\end{array}$ & $\begin{array}{l}\text { Menghadapkan siswa pada situasi teka-teki } \\
\text { (masalah) sehingga menimbulkan pertanyaan- } \\
\text { pertanyaan pada diri siswa atau kepada guru. } \\
\text { Selanjutnya guru pun akan memberikan jawaban } \\
\text { terbatas berupa jawaban "ya" atau "tidak", sehingga } \\
\text { setiap pertanyaan yang diajukan dapat dianggap } \\
\text { sebagai suatu hipotesis terbatas }\end{array}$ \\
\hline 2 & $\begin{array}{l}\text { Fase mengumpulkan } \\
\text { data melalui } \\
\text { pengujian (data- } \\
\text { gathering- } \\
\text { verification) }\end{array}$ & $\begin{array}{l}\text { Siswa berusaha mengumpullkan data informasi } \\
\text { sebanyak-banyaknya, tentang masalah yang mereka } \\
\text { hadapi. Data tersebut dapat diperoleh berdasarkan } \\
\text { kondisi objek atau menguji bagaimana proses } \\
\text { terjadinya masalah tersebut }\end{array}$ \\
\hline
\end{tabular}




\begin{tabular}{|l|l|l|}
\hline 3 & $\begin{array}{l}\text { Fase mengumpulkan } \\
\text { data } \begin{array}{c}\text { melalui } \\
\text { eksperimen (data- } \\
\text { gathering- } \\
\text { experimentation) }\end{array}\end{array}$ & $\begin{array}{l}\text { Pada phase ini dilakukan isolasai terhadap data-data } \\
\text { yang menjadi esensi masalah yang dihadapi }\end{array}$ \\
\hline 4 & $\begin{array}{l}\text { Fase mengorganisir, } \\
\text { menyusun penjelasan } \\
\text { (organizing, } \\
\text { formulating } \\
\text { explanation) }\end{array}$ & $\begin{array}{l}\text { Pada phase ini guru dapat merumuskan penjelasan } \\
\text { untuk membimbing siswa pada pemecahan masalah } \\
\text { yang terarah. Bagi siswa yang menemui kesulitan } \\
\text { dalam mengemukakan informasi yang mereka } \\
\text { peroleh untuk memberikan uraian yang jelas, maka } \\
\text { dapat memberikan penjelasan yang sederhana saja } \\
\text { dan tidak mendetail }\end{array}$ \\
\hline 5 & $\begin{array}{l}\text { Fase menganalisis } \\
\text { kegiatan proses } \\
\text { inkuiri (analysis of } \\
\text { the inquiry process) }\end{array}$ & $\begin{array}{l}\text { Pada phase ini siswa menganalisis pola-pola } \\
\text { penemuan mereka Dengan demikian siswa akan } \\
\text { banyak memperoleh tipe-tipe informasi, yang } \\
\text { sebelumnya tidak dimiliki siswa. Hal ini penting bagi } \\
\text { siswa, sebab hal tersebut dapat melengkapi dan } \\
\text { memperbanyak data yang relevan serta menunjang } \\
\text { untuk menentukan pemecahan masalah }\end{array}$ \\
\hline
\end{tabular}

Penerapan model inkuiri dapat berjalan secara efisien jika guru dapat menggunakan nurturant (pengiring) pada roses inkuirinya. Berikut ini merupakan bagan pengajaran dan nurturant model Inquiry Training (Joyice, et al., 2000). 


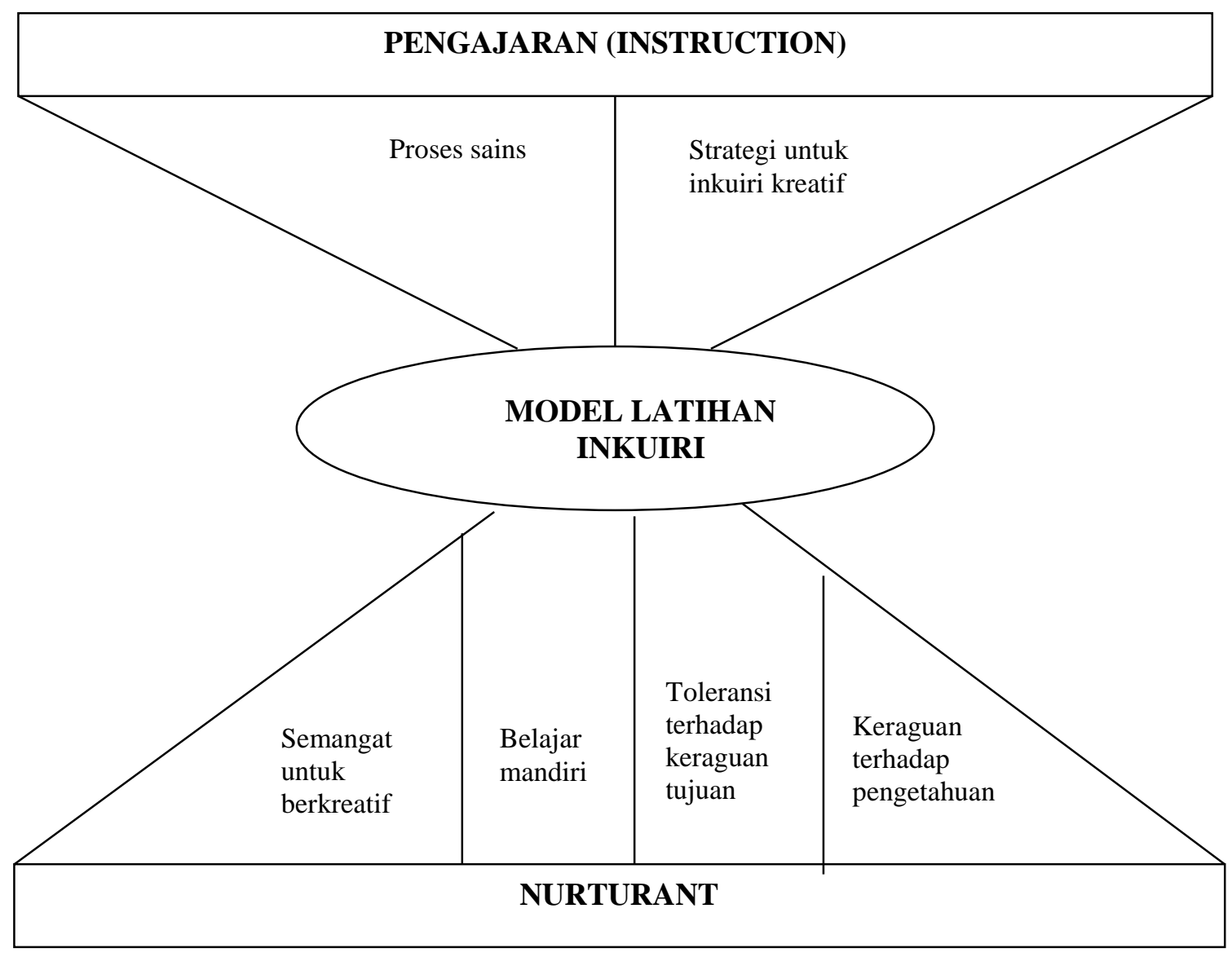

Gambar 1. Pengajaran Dan Nurturant Model Inquiry Training (Latihan Berinkuiri)

\section{2) Biological Science Inquiry (BSI)}

Schwab (Joyce, et al., 2000) mengemukakan bahwa pada model inkuiri ini siwa dilatih untuk melakukan penelitian secara mandiri. Adapun fase-fase/ sintaks dalam model ini dijelaskan pada Tabel 4.

Tabel 4. Sintaks Model Biological Science Inquiry

\begin{tabular}{|l|l|l|}
\hline No & \multicolumn{1}{|c|}{ Sintaks } & \multicolumn{1}{c|}{ Deskripsi } \\
\hline 1 & $\begin{array}{l}\text { mengemukakan area investigasi } \\
\text { kepada siswa (area of } \\
\text { investigation is posed to } \\
\text { student) }\end{array}$ & $\begin{array}{l}\text { guru menghadapkan siswa pada suatu } \\
\text { masalah }\end{array}$ \\
\hline 2 & $\begin{array}{l}\text { merumuskan masalah (student } \\
\text { structure the problem) }\end{array}$ & $\begin{array}{l}\text { siswa merumuskan masalah agar dapat } \\
\text { mengidentifikasi kesulitan penyelidikan } \\
\text { yang bisa berupa interpretasi data, } \\
\text { perolehan data kontrol eksperimen dan } \\
\text { membuat kesimpulan. }\end{array}$ \\
\hline
\end{tabular}




\begin{tabular}{|l|l|l|}
\hline 3 & $\begin{array}{l}\text { mengidentifikasi masalah } \\
\text { melalui investigasi (student } \\
\text { identify the problem in the } \\
\text { investigation) }\end{array}$ & $\begin{array}{l}\text { siswa diminta untuk menerka masalah } \\
\text { sehingga mereka dapat mengidentifikasi } \\
\text { kesulitan inkuiri }\end{array}$ \\
\hline 4 & $\begin{array}{l}\text { mempertimbangkan cara untuk } \\
\text { menyelesaikan masalah (student } \\
\text { speculate on ways to clear up } \\
\text { the difficulty) }\end{array}$ & $\begin{array}{l}\text { siswa merancang suatu kegiatan untuk } \\
\text { menyelesaikan masalah (kesulitan) }\end{array}$ \\
\hline
\end{tabular}

Sama seperti halnya pada model inquiry training, (Joyice, et al., 2000) menjelaskan pada model BSI pun terdapat nurturant yang dapat diterapkan oleh guru saat proses pembelajaran. Berikut ini merupakan bagan pengajaran dan nurturant model biological science inquiry.

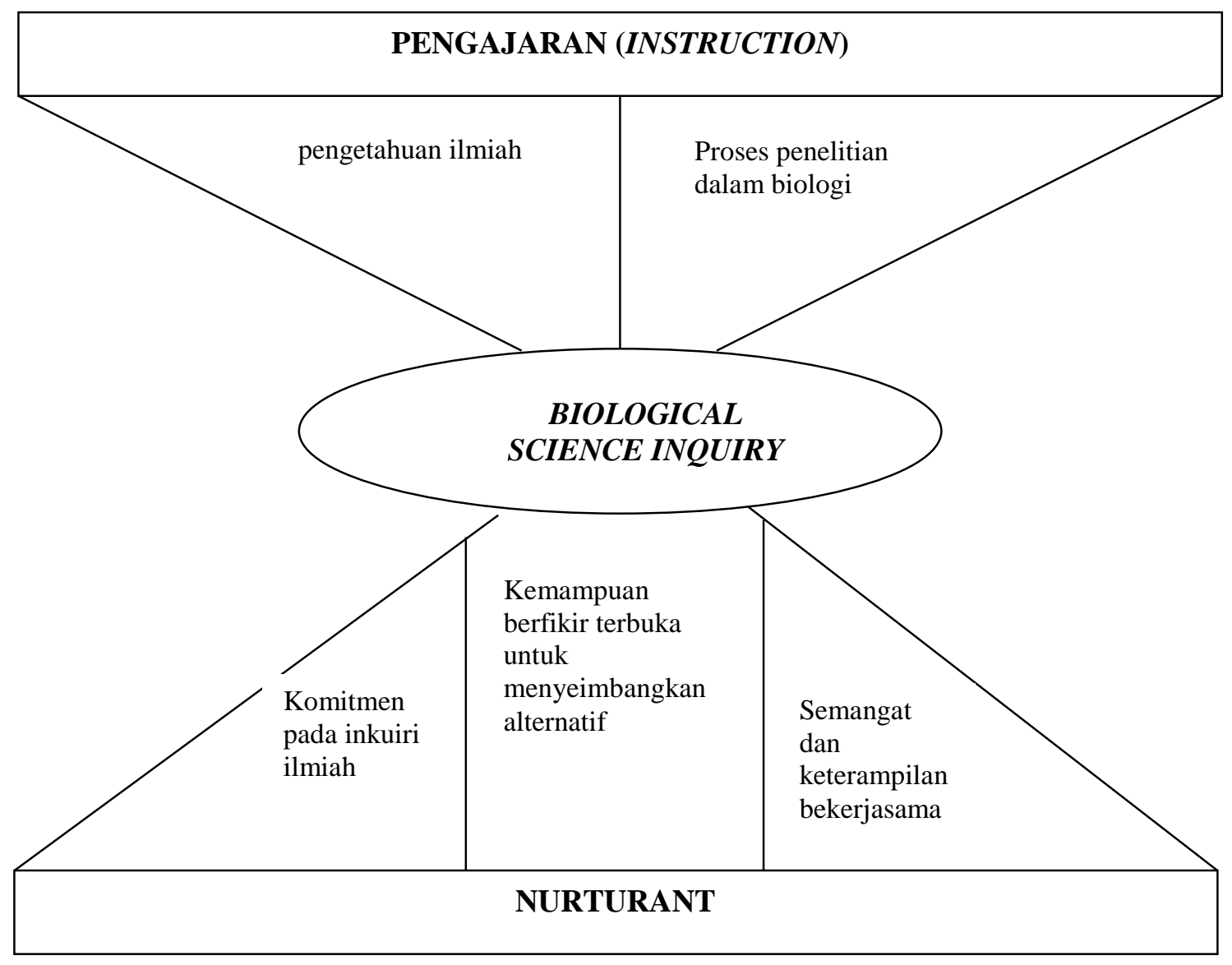

Gambar 2. Pengajaran Dan Nurturant Model Biological Science Inquiry

\section{c. Inkuiri sebagai Metode}

Inkuiri sebagai metode artinya inkuiri tersebut merupakan cara yang digunakan dalam pelaksanaan kegiatan pembelajaran. Salah satu metode pembelajaran dalam 
bidang Sains, yang sampai sekarang masih tetap dianggap sebagai metode yang cukup efektif adalah metode inquiry (Sutrisno dalam Wjanto; 2008). Haury (1993) mengutip definisi yang diberikan oleh Alfred Novak: inquiry merupakan tingkah laku yang terlibat dalam usaha manusia untuk menjelaskan secara rasional fenomenafenomena yang memancing rasa ingin tahu. Dengan kata lain, inquiry berkaitan dengan aktivitas dan keterampilan aktif yang fokus pada pencarian pengetahuan atau pemahaman untuk memuaskan rasa ingin tahu (Haury, 1993).

Alasan rasional penggunaan metode inquiry adalah bahwa siswa akan mendapatkan pemahaman yang lebih baik mengenai Sains dan akan lebih tertarik terhadap Sains jika mereka dilibatkan secara aktif dalam "melakukan" Sains. Investigasi yang dilakukan oleh siswa merupakan tulang punggung metode inquiry. Investigasi ini difokuskan untuk memahami konsep-konsep Sains dan meningkatkan keterampilan proses berpikir ilmiah siswa. Diyakini bahwa pemahaman konsep merupakan hasil dari proses berfikir ilmiah tersebut (Blosser dalam Wjanto; 2008).

Komponen penting yang harus diperhatikan pada metode inkuiri adalah sebagai berikut.

a. Question. Pembelajaran biasanya dimulai dengan sebuah pertanyaan pembuka yang memancing rasa ingin tahu siswa dan atau kekaguman siswa akan suatu fenomena. Siswa diberi kesempatan untuk bertanya, yang dimaksudkan sebagai pengarah ke pertanyaan inti yang akan dipecahkan oleh siswa. Selanjutnya, guru menyampaikan pertanyaan inti atau masalah inti yang harus dipecahkan oleh siswa. Untuk menjawab pertanyaan ini - sesuai dengan Taxonomy Bloom - siswa dituntut untuk melakukan beberapa langkah seperti evaluasi, sintesis, dan analisis. Jawaban dari pertanyaan inti tidak dapat ditemukan misalnya di dalam buku teks, melainkan harus dibuat atau dikonstruksi.

b. Student Engangement. Dalam metode inquiry, keterlibatan aktif siswa merupakan suatu keharusan sedangkan peran guru adalah sebagai fasilitator. Siswa bukan secara pasif menuliskan jawaban pertanyaan pada kolom isian atau menjawab soal-soal pada akhir bab sebuah buku, melainkan dituntut terlibat dalam 
menciptakan sebuah produk yang menunjukkan pemahaman siswa terhadap konsep yang dipelajari atau dalam melakukan sebuah investigasi.

c. Cooperative Interaction. Siswa diminta untuk berkomunikasi, bekerja berpasangan atau dalam kelompok, dan mendiskusikan berbagai gagasan. Dalam hal ini, siswa bukan sedang berkompetisi. Jawaban dari permasalahan yang diajukan guru dapat muncul dalam berbagai bentuk, dan mungkin saja semua jawaban benar.

d. Performance Evaluation. Dalam menjawab permasalahan, biasanya siswa diminta untuk membuat sebuah produk yang dapat menggambarkan pengetahuannya mengenai permasalahan yang sedang dipecahkan. Bentuk produk ini dapat berupa slide presentasi, grafik, poster, karangan, dan lain-lain. Melalui produk-produk ini guru melakukan evaluasi.

e. Variety of Resources. Siswa dapat menggunakan bermacam-macam sumber belajar, misalnya buku teks, website, televisi, video, poster, wawancara dengan ahli, dan lain sebagainya.

\section{Pengembangan Inkuiri dalam Pembelajaran}

Inkuiri terus mengalami perkembangan, terutama dalam menyongsong abad 21 yang sarat dengan tuntutan yang sangat tinggi untuk membentuk sumber daya unggul. SDM yang harus dipersiapkan untuk menghadapi tantangan abad 21 menurut Partnership for $21^{\text {st }}$ (2013) adalah mereka yang memiliki kreatifitas dan inovasi, berpikir kritis dan problem solving serta berkomunikasi dan berkolaborasi. Ministry of Education Singapore (2010) menambahkan karakteristik SDM yang dipersiapkan untuk menyongsong abad 21 adalah mereka yang memiliki kecakapan hidup (life skill), mampu mengembangkan konten kompetensi abad 21, menguasai bidang keahlian yang dimiliki, memiliki higher order thinking skills, serta liteasi ICT. Penyiapan sumber daya sesuai dengan kebutuhan abad 21 tersebut perlu dilakukan pada seluruh disiplin ilmu, termasuk sains.

Salah satu langkah konkrit yang dilakukan oleh penulis dalam pengembangan inkuiri terhadap pembelajaran adalah dengan menerapkan pembelajaran scientific inkuiri 
untuk mengembangkan keterampilan komunikasi mahasiswa. Penjelasan secara rinci terkait penerapan pembelajarannya dijelaskan pada lampiran 3.

\section{Keunggulan dan Kelemahan}

Menurut Sanjaya (2007) inkuiri memiliki keunggulan dan kelemahan dalam penerapan pembelajaran, yaitu:

a. Keunggulan

1) Pembelajaran inkuiri dianggap lebih bermakna karena selain aspek kognitif, pendekatan inkuiri mengembangkan aspek afektif dan aspek psikomotorik siswa secara seimbang

2) Memberikan ruang kepada siswa untuk belajar sesuai dengan gaya belajar siswa

3) Sesuai dengan perkembangan psikologi belajar modern yang menganggap belajar adalah proses perubahan tingkah laku berkat adanya pengalaman

4) Siswa memiliki kemampuan belajar bagus tidak terhambat oleh siswa yang lemah dalam belajar

b. Kelemahan

Adapun kelemahan inkuiri sebagai pendekatan adalah memerlukan waktu yang panjang sehingga guru sulit menyesuaikannya dengan waktu yang telah ditentukan

\section{REFERENSI}

Beyer, B.K. (1971). Inquiry in The Social Studies Classroom: a Strategy for Teaching. Ohio: Charles E Merrill Publishing Company.

Carin, A.A. \& Sund, R.B. (1989). Teaching Science Through Discovery. Ohio, Columbus: Merrill Publishing Company.

Dahar, R.W. (1991). Teori-teori Belajar. Jakarta: Erlangga.

Deboer, G.E. (2004). Historical perspectives on inquiry teaching in schools. In L. B. Flick \& N. G. Lederman (Eds.), Scientific inquiry and nature of science: Implications for teaching, learning, and teacher education. Dordrecht: Kluwer Academic Publishers.

Driver, R. (2000). Establishing the Norms of Scientific Argumentation in Classrooms, Science Education, 85 (3), 287- 312. 
Haury, L.D. (1993). Teaching Science Through Inquiry. Columbus, OH: ERIC Clearinghouse for Science, Mathematics, and Environment Education. (ED359048)

Joyce, B. \& Weil. (2000). Models of Teaching. Boston-London: Allyn and Bacon.

Khalick, A., Bell, R. L., \& Lederman, N. G. (1997). The nature of science and instructional practice: Making the unnatural natural. Science education, 82(4), 417-436.

Mariana, I.A. \& Praginda, W. (2009). Hakikat IPA dan Pendidikan IPA. Bandung: PPPPTK IPA

National Academy of Sciences. (2000). Inquiry and theNational Science Education Standards. Washington DC: National Academic Press.

National Science Teacher Assocation in Collaboration with the Association for the Education of Teacher Science. (1998). Standar for Science Teacher Preparation.

NRC (National Research Council). (1996). The National Science Education Standards. Washington DC: National Academic Press.

Rustaman, N.Y. (2005). "Kemampuan Dasar Bekerja Ilmiah dalam Pendidikan Sains dan Asesmennya". Proceeding of The First International Seminar on Science Education.

Sanjaya, W. (2007). Pendekatan Pembelajaran Berorientasi Standar Proses Pendidikan. Jakarta, Kencana.

Sumatowa, U.2010.Pembelajaran IPA di Sekolah Dasar.Jakarata:Indeks.

Suwara, P. (2008). Model Pembelajaran Inkuiri Terhadap Peningkatan Keterampilan Proses Sains pada Konsep Transportasi pada Tumbuhan [Online]. Tersedia: http://www.wordPress.com [22 Maret 2009]

Toharudin, U, dkk. 2011. Membangun Literasi Sains Peserta Didik. Bandung: Humaniora.

Trowbridge, W. \& Bybee, W. (1990). Becoming a Secondary School Science Teacher. Fifth Edition. Ohio: Merrill Publishing Company.

Wenning, C. J. (2011). Experimental Inquiry in Introductory Physics Courses. Journal Of Physics Teacher Education. 6 (2).

(2006). A Generic Model for Inquiry-Oriented Labs in Postsecondary Introductory Physics. Journal Physics Education. 2 (3), pp 24-33 
(2005). Levels of Inquiri: Hierarchies of Pedagogical Practices and Inquiri Processes. Journal Of Physics Teacher Education. 2 (3)

Wjanto. (2008). Metode Pembelajaran Inquiry [Online]. Tersedia: http://www.wordPress.com [22 Maret 2009]

Wonorahardjo, S. 2010. Dasar-dasar Sains. Jakarta: Indeks. 